\title{
The joint Australian-Indonesian archaeological expedition to South Sulawesi in 1969 in context
}

\author{
Campbell Macknight
}

\begin{abstract}
The original impetus for the joint Australian-Indonesian archaeological expedition that visited South Sulawesi in July and August 1969 can be traced to the beginning of the 20th century, but its more immediate background lay in a particular conjunction of personal, intellectual, political and security factors in both Indonesia and Australia. The opportunity to apply radiocarbon dating and an interest in stone tool typology were important aspects of the archaeological work itself. The expedition was highly successful in terms of its objectives and the archaeological data it recovered has continued to attract attention even as research interests have shifted to new questions. Participation in the work of the expedition also opened up opportunities in unexpected areas, which some of those associated with the expedition's activities have followed up in subsequent years. The conduct of the expedition established a precedent for collaboration between local, national and foreign researchers, which has been particularly happy and productive.
\end{abstract}

Keywords: Sulawesi archaeology, Australian-Indonesian collaborations, Sulawesi history

\section{Pre-1969 context}

The oldest continuous area of research collaboration between Indonesians and Australians is associated with the prehistoric archaeology of Sulawesi. Of course, scholars from other countries have also been involved, but the Australian connection goes back to 1937 with a continuing web of interaction down the decades.

The story really begins, however, as a small element in the obsessive collecting of the enigmatic Swiss second cousins, Paul and Fritz Sarasin of Basel: Paul the tall and dreamy one; Fritz the organiser and master of public relations. They met as students of zoology and their natural history interests were always central, but in the late 19th-century enthusiasm for Darwinian thought and colonial expansion, this scientific vision easily encompassed specimens of humanity. 
This investigation of 'anthropology', as they understood it, led them, when they were already in Sulawesi, to seek out the groups they knew as Toála (literally bushmen and its equivalents in many languages). ${ }^{1}$

In 1902 in the hills of south Bone, the Sarasins found people apparently living in caves and they recovered from the caves a collection of artefacts, including finely worked stone tools and points. They assumed that the current inhabitants and the makers of the stone tools were directly connected, though they lacked any means of directly dating the tools. In his discussion, Paul Sarasin draws a fateful comparison:

This apparent mixture [of stone tool types], which at first glance just gives the impression of being Magdalenian, appears in a still greater measure to relate to actual present-day tribes which maintain a stone age culture, such as, in particular, the Australians among whom the absolutely crudest tools are found alongside good Neolithic work (translated by author from Sarasin and Sarasin 1905a:25). ${ }^{2}$

Right from the beginning, connections with Australia were in the air. ${ }^{3}$

Almost exactly 30 years later, a chain of events began that led to further discoveries. In December 1932, Abdul Maula, a school inspector, reported that on a tour of inspection he had come across a bronze statue in a government guest house near the mouth of the Karama River in West Sulawesi. It just so happened that Abdul Maula's brother was Nuruddin Daeng Magassing, the assistant, colleague and very good friend of A.A. Cense, the government linguist and well-known to L.J.J. Caron, then Governor of Celebes and a considerable scholar in his own right. Things moved with lightning speed; since the governor was visiting the area anyway, he collected the statue and sent it off to the museum in Batavia, where it still is. On 20 May 1933, Cense was dispatched to make field investigations and a week or so later was excavating stone axes and earthenware on the site of Sikendeng. He also heard that similar artefacts had been found at Kalumpang, up the Karama River. In August, the governor was touring again and visited the sites. He decided to call in P.V. van Stein Callenfels, then the leading prehistoric archaeologist in the Indies. The archaeological discovery of the Karama valley had begun, but still had a long way to go. ${ }^{4}$

1 The name deserves some comment. In the German text, the name is consistently written with an acute accent on the middle syllable; this is probably intended to mark the stress. Matthes in his Bugis dictionary (1874:872) gives a form that in modern orthography is rendered Tau-ale for the Dutch een boschmensch, and he goes on to note that the term is also used for its counterpart in Malay, orang-utan. The standard modern Bugis form would be Toaleq. I can find no Bugis form of the word for bush or forest ending in $/-a^{\prime} \mid$ or $/-a /$, though Cense in his Makasar dictionary (1979:7) gives ala' as a dialect form influenced by the Bugis ale'. Specifically, in relation to the stone tools, Paul Sarasin uses Toalien as an adjective. Van Heekeren, in Dutch, writes Toale for the people and Toaliaan for the stone tools (van Heekeren 1969:112-113) and, in English, Toale and Toalean (van Heekeren 1972:109). The widespread reliance on this later work of van Heekeren seems to have established the usage Toalean in English. I use the Bugis form, Toaleq, here for the people.

2 This is not the only comparison with Australian material to be found in the Sarasins' work. In his discussion of the knotted string bags found in the caves, Paul refers to Brough Smyth's description of rather simpler examples from Victoria (Sarasin and Sarasin 1905a:21-22; referring to Smyth 1878:343). A few weeks later, at Kantissang, southeast of Pangkajene, Paul is comparing the sticks used to throw at birds in the rice fields to Australian boomerangs and quotes the then Governor of Celebes, G.W.W.C. Baron von Hoévell, who had already made the same observation in an ethnographic article (Sarasin and Sarasin 1905b:229-230).

3 For a detailed record of the Sarasin collections from the Toalean sites, see Bulbeck (2006). Simon (2015) provides a very thorough recent account of the lives, work and intellectual background of the Sarasins. Schär (2015a, 2015b) relates the lives and work of the Sarasins to the wider scientific, political and cultural themes of the time. As this recent explosion of scholarly interest shows, from the time of Alfred Russel Wallace's travels in the middle of the 19th century, research in Sulawesi has played an important role in European thought about the 'deep history' of the world.

4 See Anggraeni (2012). This paragraph is based on the Cense papers in the Koninklijk Instituut voor Taal-, Land- en Volkenkunde in Leiden. The most relevant for this matter are translated in Anggraeni (2012:371-373). 
Once in Sulawesi, however, Callenfels also followed up other archaeological prospects. ${ }^{5}$ He began by revisiting the area where the Sarasins had found the Toaleq, and towards the end of 1933 was excavating sites there with the assistance of Cense and H.D. Noone from Malaya. Van Heekeren (1972:110) says that Nuruddin had been to the area with the Sarasins and I strongly suspect that Nuruddin played a critical role in guiding the new researchers.

Van Heekeren (1972:106-125) provides a detailed account of excavations and discoveries over the next few years. A striking feature of this period is the way in which various people were drawn in and worked together. The leadership of Cense and Nuruddin seems to have been important in this. For example, in 1933, Cense had noticed a Toalean site at Ara in the southeast, but when in 1936 he and Nuruddin returned there with van Heekeren, who was not yet formally employed as an archaeologist, an over-enthusiastic district officer had already seriously disturbed the site. After Ara, van Heekeren moved on to Leang Karassak, which seems to have been the first cave near Maros to have been excavated. This spectacular karst area, and especially the Bantimurung waterfall, had been admired by visitors since, at least, the middle of the 18 th century; ${ }^{6}$ a century later, Alfred Russel Wallace rhapsodised over its wealth of butterflies. The Sarasins too had visited the Leang Leang valley, but did not notice the cave deposits.

The following year, 1937, saw major campaigns. Van Heekeren continued digging in the Maros karst sites and, under Callenfels's overall direction, two cave sites further north were dug, as well as Batu Ejayya and Panganreang Tudea near Bantaeng. Callenfels had recruited to help him-in addition to his loyal assistant, Munaf, who actually did the work-two younger men. Dr W.J.A. Willems was a young archaeologist whom Callenfels had met in Groningen in 1932 and whom he had invited to succeed him as prehistorian in the Archaeological Service from the beginning of 1938. This fieldwork in Sulawesi was intended to introduce Willems to the realities of working in Southeast Asia.7 The second young man was F.D. McCarthy from the Australian Museum in Sydney, who was also meant to be learning how to dig.

It is possible to reconstruct the chain of connections that led McCarthy to come to Sulawesi. On his home visit to the Netherlands in 1932, Callenfels had also met Professor J.L. Shellshear, a physical anthropologist then from Hong Kong. In 1935, Shellshear retired to Sydney where, in settling into the local scene, he soon met McCarthy, then an assistant ethnologist at the museum. About this time, McCarthy also took a course in physical anthropology from Professor A.N.StG. Burkitt. McCarthy credits Shellshear and Burkitt with 'arranging' his trip (McCarthy 1984:74). Another possible contact was through H.V.V. Noone, who was helping McCarthy with his work classifying Australian stone tools and was the father of H.D. Noone, who had dug with Callenfels in 1933. In 1938, McCarthy went on to visit H.D. Noone in the Malayan jungle. ${ }^{8}$ McCarthy seems to have been the source for some Australian ideas in Sulawesi archaeology, such as the term muduk for the double-ended bone point, and he was probably the first to recognise geometric microliths. ${ }^{9}$

Callenfels died in 1938 and World War II put a stop to further work for almost a decade. Van Heekeren, however, now officially attached to the Archaeological Service, was active again in Sulawesi between 1947 and 1950, until the troubles of that time made fieldwork impossible until

5 Callenfels was not entirely unprepared for this. On his way back to the Indies at the end of 1932, he visited Fritz Sarasin who was still living in Basel (Swanenburg 1951:213).

6 See de Roever and Brommer (2008) for various maps and drawings from the 18th century.

7 Swanenburg (1951:212 and Plate 29) provides information on who Callenfels met at this time. See also van Stein Callenfels (1938).

8 In addition to the references in the previous note, see McCarthy (1984). There is more work to be done on McCarthy's papers about his visit to Southeast Asia in 1937 and 1938. McCarthy also mentions meeting Willems in Sydney in the early 1940s, but Willems gave up his career in archaeology. Bulbeck (2000) also discusses McCarthy's visit and other matters relevant to this discussion.

9 Willems was back in the field in 1939, though only to show the restricted geographic range of the Toalean. 
the late 1960s. He then went on to other interests. Indonesia was not forgotten, however, and, in 1957, the first edition of his invaluable synthesis, The Stone Age of Indonesia, was published. This provides an account of all this earlier work. ${ }^{10} \mathrm{He}$ also had various Australian visitors in the Netherlands; in particular, John Mulvaney visited him in 1961 (Mulvaney 2011:149). In March 1968, van Heekeren returned to Indonesia in connection with preparing the second edition of The Stone Age of Indonesia, and this trip included revisiting the Maros and Cabengnge sites with his protégé, friend and successor as prehistorian in the Archaeological Service, R.P. Soejono. ${ }^{11}$

Another visitor to van Heekeren in the Netherlands in 1961 was Jack Golson, who had just been appointed to a position in the Research School of Pacific Studies at The Australian National University in Canberra. In the course of a long return trip to Australia, Golson also met Soejono in Bali in 1962 and established a strong connection. In 1966, Mulvaney met Soejono for the first time at the Pacific Science Congress in Tokyo (Mulvaney 2011:142). ${ }^{12}$

It is not clear who first had the idea of a joint team to continue research in Sulawesi in 1969, but circumstances on both sides were favourable. ${ }^{13}$ Soejono had moved from Bali to Jakarta and was keen to continue work on the sites in Sulawesi he had recently inspected with van Heekeren. Although Golson had shifted his interest to New Guinea, Mulvaney had been working in north Australia for some years and, in looking for external origins or linkages, it was natural to gaze northwards. He was, of course, well aware of McCarthy's ideas (1940) and McCarthy himself was by now in Canberra as founding principal of the Australian Institute of Aboriginal Studies, as it was then known. Among Mulvaney's PhD students, Ian Glover was excavating sites in then Portuguese Timor and I was investigating trepangers from Makassar in Arnhem Land. I had also visited Jakarta in early 1966 and had been allowed to study the museum's holdings of materials from excavations in Sulawesi. In late 1968, Soejono came to Canberra to help plan a combined expedition.

\section{The 1969 expedition and its aftermath}

R.P. Soejono and John Mulvaney were the joint leaders of the Australian-Indonesian archaeological expedition to Sulawesi. ${ }^{14}$ The other members on the Indonesian side were Basuki, who served as draftsman, and Teguh Asmar, later director of Indonesia's National Museum (in Jakarta). On the Australian side were Ian and Emily Glover and myself. We worked in two areas. The first was around Callenfels's site of Batu Ejayya near Bantaeng, where we re-excavated the main cave and another shelter nearby, as well as exploring the area for further sites. Conditions were rough; it took four hours in a large truck to reach Bantaeng on the main road from Makassar, while the side road up to Campagaloe near the sites was even worse. My most enduring memory is the constant surveillance by a crowd of onlookers - on the site, out in the fields or on the street outside the village house where we ate and slept. This was compensated for, to some extent, by the companionship of several young assistants-among them, Mukhlis Paeni was still an undergraduate at Universitas Hasanuddin, while Darmawan Mas'ud Rahman and Harun Kadir were already graduates. It was quite a team, given all our future careers (Figure 2.1). The assistants did not follow us to the Maros area where conditions were much easier and we employed several

\footnotetext{
10 Hooijer (1950) also offers a useful commentary on earlier excavations.

11 van Heekeren (1969) is an important source on this trip and his earlier work.

12 I wish to thank both John Mulvaney and Jack Golson for conversations about these contacts.

13 The end of gerombolan (bandit) control of much of the interior was also critical. At least travel was now safe, though researchers were subject to careful oversight and the infrastructure of roads and accommodation was in a very poor state.

14 See Mulvaney (2011) for an account of Mulvaney's career; Simanjuntak et al. (2006) give a picture of Soejono's remarkable contributions to Indonesian archaeology.
} 
local men to help with excavation. We dug in Leang Burung 1, Ulu Leang 1 and Leang Karassak, and recovered broken burial earthenware from Ulu Leang 2 and Ulu Wae. We also explored various other sites with deposit and, in many cases, hand stencils and other rock art.

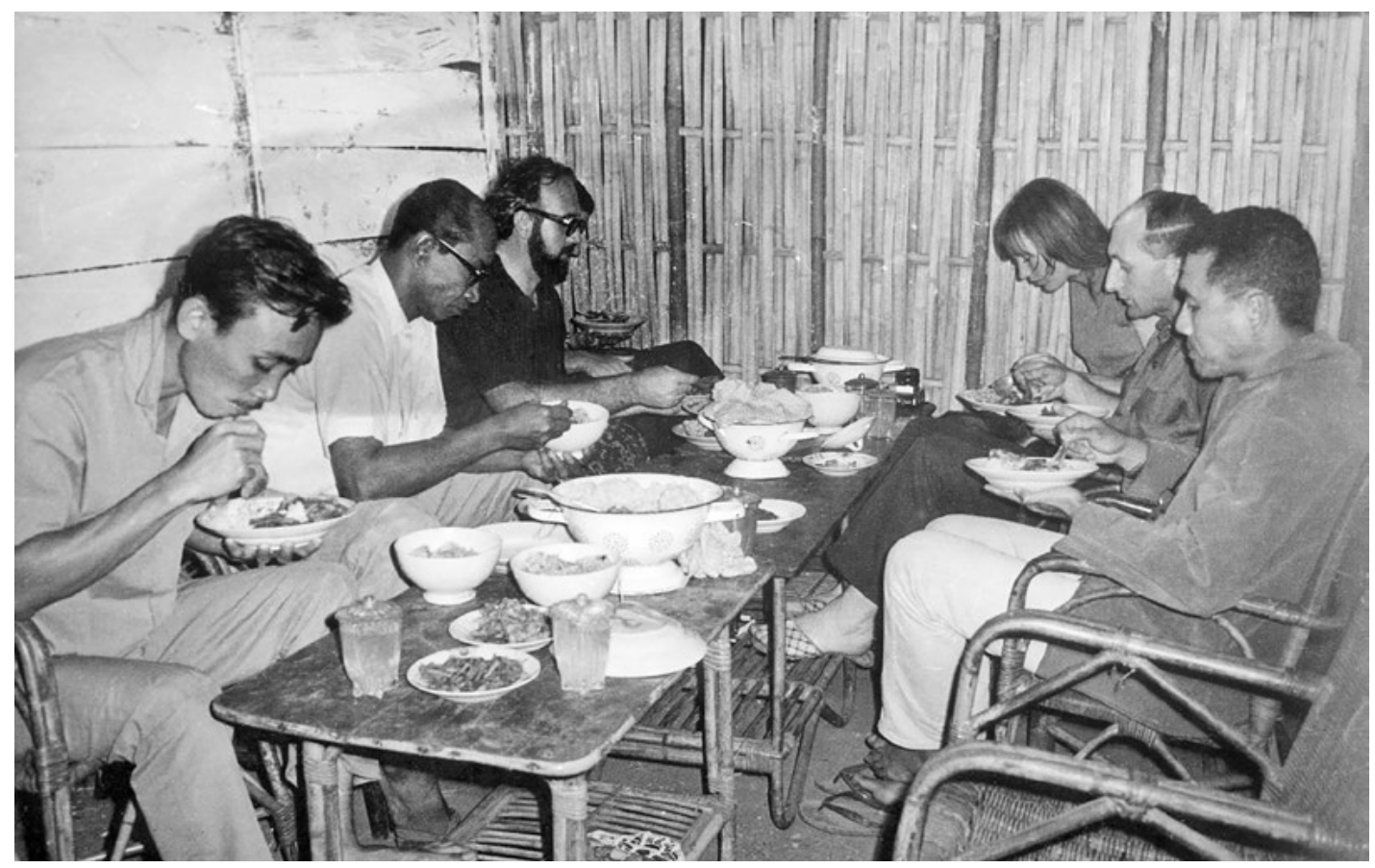

Figure 2.1: Dinner at Campagaloe, near Batu Ejayya in 1969.

From the left: Harun Kadir, Basuki, lan Glover, Campbell Macknight (just visible behind), Emily Glover, John Mulvaney and R.P. Soejono.

Source: Photograph by Teguh Asmar.

This is not the place to discuss the archaeological results of this work in detail. Two brief articles were published very promptly (Mulvaney and Soejono 1970, 1971). These reported the first radiocarbon dates for Sulawesi and, not unexpectedly, dated the Toalean stone industry well back into the Holocene. In due course, Chapman (1986) produced more detailed analysis of the stone tools, while Bulbeck and his students followed up with studies of a wider range of materials. ${ }^{15}$ What is most remarkable, however, is the variety of arrangements, projects, friendships and interests that can be traced back to this 1969 expedition.

Most obviously, Ian Glover returned and dug further in the Maros caves, obtaining the first Pleistocene dates from Leang Burung 2 (Glover 1981). One of Soejono's objectives in 1969 had been to investigate the possibility of setting up a branch of the then Lembaga Purbakala dan Peninggalan Nasional in Makassar. Its first head, Hadimuljono, visited Canberra before taking up his post. One of the continuing interests of this branch and its successors has been research into the art and archaeology of the Maros caves, as this volume demonstrates so well.

Our interests were not just prehistoric. Soejono with, I think, Teguh Asmar, took the opportunity to inspect Islamic sites in Soppeng, and the Glovers endured a very rough trip up to Tana Toraja to see some standing stones, as well as the usual sights.

15 See, especially, Bulbeck et al. (2000) for a comprehensive study of the Toalean culture. The suggested links with Australian stone technology, which still feature in Mulvaney and Soejono's articles, receive less attention in more recent work. Bulbeck (2000:48) helpfully lists the work of his students and others on the ceramic and faunal materials. 
In the local government office in Bantaeng, we saw a table laid out with Chinese and other ceramic pieces recovered from pre-Islamic graves. This revealed the potential for systematic study of the material. One of Hadimuljono's great achievements was to bring this businesssince there were considerable financial interests involved-under control. A few weeks later in Leang-Leang, I was shown a steel rod for probing the ground in the search for ceramics. In 1970, Uka Tjandrasasmita and Abu Ridho conducted the first careful excavation of burial sites from this period in Takalar and near Pangkajene (Purbakala 1970). ${ }^{16}$ Later, Hadimuljono and I published an article together that provided a base line for so much further work (Macknight and Hadimuljono 1983).

Even more important for my future-through the good offices of Andi Abubakar Punagi, Abdurrahim and La Side, all board members of the Yayasan Kebudayaan Sulawesi Selatan dan Tenggara-I was able to view the collection of Bugis and Makasar manuscripts, most of which had been assembled by Cense in the 1930s. It was then that I dimly glimpsed the potential for investigating the early history of South Sulawesi by combining ceramic and textual sources. ${ }^{17}$ There is no room here to trace the development of this vision, especially through the work of Ian Caldwell, David Bulbeck and Steve Druce, but one of its great pleasures has been working with so many Indonesian friends and colleagues. Let me here just acknowledge the scholarship and friendship of two so that they do not get forgotten among the archaeologists: Professor Andi Zainal Abidin and the inimitable Muhammad Salim.

Lastly, through Abdurrahim, Nuruddin's successor as Cense's assistant and, indeed, Cense's successor as the indispensable contact for visiting scholars, I met Mangngellai Daeng Maro who had twice sailed to Arnhem Land with his father in search of trepang. ${ }^{18}$ This was a contact later followed up by Peter Spillett. Even more evocative, I spent a day sailing with the bupati (district head) of Maros on a pajala to Barrang Lompo. ${ }^{19}$ We ended up well after dark on the beach in front of Fort Rotterdam; an aide was sent to find a vehicle and the bupati drove us back to Maros in the local ambulance. Someone was deputed to drop me off last of all in the middle of the night - and I had to get up to continue digging Leang Burung in the morning. A few days later, together with Teguh Asmar and Daud Limbungan, the only assistant from Batu Ejayya brave enough to take to the water, I sailed out to Barrang Lompo on a soppe for further enquiry about trepang and to collect a sample of sherds that littered the shallows. ${ }^{20}$

\section{Conclusion}

The world the Sarasins found when they came to Sulawesi well over a century ago is now barely imaginable, and even the late colonial arrangements within which McCarthy was a welcome visitor are long gone. While, as the career of Nuruddin Daeng Magassing demonstrates, Indonesians were active participants in early research too, the 1969 expedition, under the joint leadership of Mulvaney and Soejono, set a precedent for collaboration and friendship

16 Projek Penggalian di Sulawesi Selatan/The South Sulawesi Excavation Project in 1970 was funded by a most distinguished list of sponsors, with a committee chaired by Adam Malik, then minister for foreign affairs. The strong diplomatic interest in this project contrasts with the official Australian disinterest in the 1969 expedition as described by Mulvaney (2011:149-150).

17 See Macknight (1975) for an early exploration of this potential. It should also be noted that the chair of the Yayasan board was Andi Pangerang Petta Rani who graciously took an interest in later work.

18 In the 1960s, I corresponded with Cense, who had written a classic article on the trepangers in northern Australia, and had the very great pleasure of meeting him in the Netherlands in 1975. On trepanging, see Macknight (1976) and, most recently, Clark and May (2013).

19 A pajala is a fishing boat with a tripod mast and large rectangular sail.

20 A soppe is an outrigger canoe with a single mast and smaller sail. 
between Indonesian and, especially, Australian researchers in Sulawesi that endures to this day. This volume is testament to the spectacular results of this collaboration; the friendship should also be celebrated.

\section{Author biography}

Campbell Macknight College of Asia and the Pacific, The Australian National University, Canberra, Australia

\section{References}

Anggraeni. 2012. The Austronesian migration hypothesis as seen from prehistoric settlements on the Karama River, Mamuju, West Sulawesi. Unpublished PhD thesis, School of Archaeology and Anthropology, The Australian National University, Canberra.

Bulbeck, D. 2000. A historical perspective on the Australian contribution to the practice of archaeology in Southeast Asia. Australian Archaeology 50:45-53. doi.org/10.1080/03122417.2000.11681665 (accessed 5 June 2018).

Bulbeck, D. 2006. Economic and technological change during the middle and late Holocene in the Lamoncong highlands, South Sulawesi, Indonesia. In E.A. Bacus and I. Glover (eds), Uncovering Southeast Asia's Past: Selected Papers from the 10th International Conference of the European Association of Southeast Asian Archaeologists, pp. 393-410. Singapore: NUS Press.

Bulbeck, D., M. Pasqua and A. Di Lello. 2000. Culture history of the Toalean of South Sulawesi, Indonesia. Asian Perspectives 39(1-2):71-108. doi.org/10.1353/asi.2000.0004.

Cense, A.A. 1979. Makassaars-Nederlands Woordenboek. The Hague: Martinus Nijhoff. doi.org/10.1002/ j.1834-4453.1986.tb00127.x (accessed 5 June 2018).

Chapman, V. 1986. Inter-site variability in southwest Sulawesi: Results of the 1969 Australian-Indonesian Archaeological Expedition. Archaeology in Oceania 21(1):76-84.

Clark, M. and S.K. May (eds). 2013. Macassan History and Heritage: Journeys, Encounters and Influences. Canberra: ANU E Press.

de Roever, A. and B. Brommer. 2008. Grote Atlas van de Verenigde Oost-Indische Compagnie/Comprehensive Atlas of the Dutch United East India Company, III Indische Archipel en Oceanië/Malay Archipelago and Oceania. Voorburg: Asia Maior/Atlas Maior.

Glover, I.C. 1981. Leang Burung 2: An upper Palaeolithic rock shelter in South Sulawesi, Indonesia. In G.-J. Bartstra and W.A. Casparie (eds), Quaternary Research in Southeast Asia, pp. 1-38. Modern Quaternary Research in Southeast Asia, Volume 6. Rotterdam: A.A. Balkema.

Hooijer, D.A. 1950. Man and other Mammals from Toalian Sites in south-western Celebes. Verhandelingen der Koninklijke Nederlandse Akademie van Wetenschappen, Afd. Natuurkunde. Amsterdam: NorthHolland Publishing Company.

Macknight, C.C. 1975. The emergence of civilisation in South Celebes and elsewhere. In A. Reid and L. Castles (eds), Pre-colonial State Systems in Southeast Asia. (Monographs of the Malaysian Branch of the Royal Asiatic Society No 6), pp. 126-135. Kuala Lumpur: Perchetakan.

Macknight, C.C. 1976. The Voyage to Marege': Macassan Trepangers in northern Australia. Melbourne: Melbourne University Press. 
Macknight, C.C. and Hadimuljono. 1983. Imported ceramics in South Sulawesi. Review of Indonesian and Malaysian Affairs 17:66-91.

Matthes, B.F. 1874. Boegineesch-Hollandsch Woordenboek. The Hague: Martinus Nijhoff.

McCarthy, F.D. 1940. A comparison of the prehistory of Australia with that of Indo-China, the Malay Peninsula and the Netherlands East Indies. In F.N. Chasen and M. Tweedie (eds), Proceedings of the Third Congress of Prehistorians of the Far East: Singapore, 24th January - 30th January, 1938, pp. 30-50. Singapore: Government Printing Office.

McCarthy, F.D. 1984. A coat of paint. Australian Aboriginal Studies 2(1984):72-81.

Mulvaney, D.J. 2011. Digging Up A Past. Sydney: UNSW Press.

Mulvaney, D.J. and R.P. Soejono. 1970. The Australian-Indonesian Archaeological Expedition to Sulawesi. Asian Perspectives 13:163-177.

Mulvaney, D.J. and R.P. Soejono. 1971. Archaeology in Sulawesi, Indonesia. Antiquity 45(177):26-33. doi.org/10.1017/S0003598X00069015 (accessed 5 June 2018).

Purbakala, J. 1970. The South Sulawesi Excavation: Final Report. Jakarta: Jajasan Purbakala.

Sarasin, P. and F. Sarasin. 1905a. Versuch einer Anthopologie der Insel Celebes. Erster Teil: Die Toála-höhlen von Lamontjong. (Materialien zur Naturgeschichte der insel Celebes, V Band, 1 Teil). Wiesbaden: C.W. Kriedel's Verlag.

Sarasin, P. and F. Sarasin. 1905b. Reisen in Celebes: Ausgeführt in den Jahren 1893-1896 und 1902-1903. Wiesbaden: C.W. Kriedel's Verlag.

Schär, B.C. 2015a. Earth scientists as time travelers and agents of colonial conquest: Swiss naturalists in the Dutch East Indies. Historical Social Research/Historische Sozialforschung 40(2):67-80.

Schär, B.C. 2015b. Tropenliebe: Schweizer Naturforscher und niederländischer Imperialismus in Südostasien um 1900. Frankfurt: Campus Verlag.

Simanjuntak, T., M. Hisyam, B. Prasetyo and T.S. Nastiti (eds). 2006. Archaeology: Indonesian Perspective, R.P. Soejono's Festschrift. Jakarta: LIPI Press.

Simon, C. 2015. Reisen, Sammeln und Forschen: Die Basler naturhistoriker Paul und Fritz Sarasin. Basel: Schwabe.

Smyth, R.B. 1878. The Aborigines of Victoria: With Notes relating to the Habits of the Natives of other Parts of Australia and Tasmania, compiled from various Sources for the Government of Victoria. Melbourne: Government Printer.

Swanenburg, B.D. 1951. Iwan de verschrikkelijke. Leven en werken van Dr. P. V. van Stein Callenfels. Maastricht: Leiter-Nypels.

van Heekeren, H.R. 1957. The Stone Age of Indonesia. Verhandelingen van het Koninklijk Instituut voor Taal-, Land- en Volkenkunde 21. The Hague: Martinus Nijhoff.

van Heekeren, H.R. 1969. De onderste steen boven: Belevenissen van een globetrotter. Assen: Van Gorcum.

van Heekeren, H.R. 1972. The Stone Age of Indonesia. Revised edition. Verhandelingen van het Koninklijk Instituut voor Taal-, Land- en Volkenkunde 61. The Hague: Nijhoff. doi.org/10.26530/ OAPEN_613383.

van Stein Callenfels, P.V. 1938. Archeologisch onderzoek in Celebes. Tijdschrift van het Nederlandsch Aardrijkskundig Genootschap 55:138-142. 
This text is taken from The Archaeology of Sulawesi: Current Research on the Pleistocene to the Historic Period, edited by Sue O'Connor, David Bulbeck and Juliet Meyer, published 2018 by ANU Press, The Australian National University, Canberra, Australia.

doi.org/10.22459/TA48.11.2018.02 